Brazilian Journal

of Chemical

ISSN 0104-6632

Engineering

\title{
THE EFFECT OF TEMPERATURE AND FLOW RATE ON THE CLARIFICATION OF THE AQUEOUS STEVIA-EXTRACT IN A FIXED-BED COLUMN WITH ZEOLITES
}

\author{
I. C. C. Mantovaneli, E. C. Ferretti, M. R. Simões and C. Ferreira da Silva* \\ Universidade Estadual do Oeste do Paraná, Centro de Engenharias e Ciências Exatas, \\ Rua da Faculdade, 645, Jardim La Salle, Toledo - Paraná \\ Phone/Fax: (45) 252-3535, CEP 85903-000, Brazil \\ E-mail: msimoes@unioeste.br \\ E-mail: classiusferreira@yahoo.com.br
}

(Received: June 13, 2002 ; Accepted: April 2, 2004)

\begin{abstract}
Stevia is being used as a sweetener due to its low calorific value and its taste, which is very similar to that of sucrose. After extraction from dried leaves, stevia extract is dark in colour so needs to be clarified for better acceptance by consumers. Adsorption is one of the most important processes in this clarification. In this work the clarification of extract stevia extract in fixed-bed columns with calcium zeolites was studied. Two temperatures $\left(10^{\circ} \mathrm{C}\right.$ and $\left.30^{\circ} \mathrm{C}\right)$ and six different flow rates $(2,5,9,12,16$ and $19 \mathrm{~mL} / \mathrm{min})$ were studied. The results showed that the mass-transfer coeffcient increases with an increase in flow rate and the length of unused bed reaches a maximum at $9 \mathrm{~mL} / \mathrm{min}$ for both temperatures. The fit of the Thomas model with the breakthrough data was not very good.

Keywords: stevia, zeolite, breakthrough curves, clarification, Thomas model
\end{abstract}

\section{INTRODUCTION}

The worldwide demand for high-potency sweeteners is expected to increase, especially with the new practice of blending different sweeteners. The leaves of the sweet herb from Paraguay, Stevia rebaudiana Bertoni produce an alternative to sucrose with the advantage that stevia sweeteners are natural plant products. In addition, the functional and sensory properties of stevia are superior to those of many other high-potency sweeteners (Brandle et al., 1998). Stevia consumption amounts to $300 \mathrm{t} \mathrm{year}^{-1}$ in countries such as Brazil and Japan (Nishiyama et al., 1992).

According to Crammer and Ikan (1987), the leaves of the Stevia rebaudiana plant contain a complex mixture of diterpenes, triterpenes, tannins, stigmasterol, volatile oils and eight sweet diterpene glycosides. They are stevioside, steviolbioside, rebaudiosides $\mathrm{A}, \mathrm{B}, \mathrm{C}, \mathrm{D}$ and $\mathrm{E}$ and dulcoside $\mathrm{A}$ (Fig. 1). Rebaudioside A is more stable and much sweeter and tastes better than stevioside. Rebaudioside E is as sweet as stevioside, and rebaudioside $\mathrm{D}$ is as sweet as rebaudioside $\mathrm{A}$, while the remaining diterpene glycosides are not as sweet as stevioside.

The relative sweetness of these diterpenes glycosides depends on concentration and the environment. Collectively they make stevia 100 to 300 times sweeter than sucrose (Phillips, 1987).

Several research projects have found no significant toxic activities for stevioside in some biological systems. Stevioside does not have teratogenic (Yodyinguard and Bunyawong, 1991),

*To whom correspondence should be addressed 
mutagenic (Suttajit et al, 1993) or carcinogenic (Xili et al., 1992) effects.

Dried leaves are infused in hot water or acohol (ethanol or methanol) in order to obtain their extract, which is a colloidal solution with brownish particles. This extract must be clarified prior to commercialisation so that it is completely limpid. One method of clarification is precipitation of the colloidal particles with solvents, but these solvents are usually toxic to humans and after clarification have to be totally removed from the sweetener. Ultrafiltration and microfiltration are chemicalfree treatments used to remove impurities from the extract but ion exchange and adsorption column chromatography have been widely used for refining sweeteners (Zhang et al., 1999).

On the other hand, adsorption is a promising process for clarification because it is safe and does not use toxic solvents. In this context, zeolites have been used as adsorbents to clarify stevia extract (Kodaka, 1977; Moraes, 2000).

Moraes (2000) tried zeolite type $\mathrm{X}$ ion exchanged with calcium and barium in this clarification. The best results were obtained for the zeolite exchanged with calcium, and batch tests showed that as the temperature increases the clarification becomes worse. Moreover, the use of zeolite exchanged with barium caused the taste of the extract to become salty.

Shi et al. (2002) introduced quaternary ammonium groups into conventional resinic adsorbent used to adsorb stevia glycosides in production. The mechanism of adsorption and decolourisation was also studied, and it was found that adsorption of stevia glycosides was based on hydrophobic interactions, but decolourisation was based on both ion exchange and hydrophobic interactions.

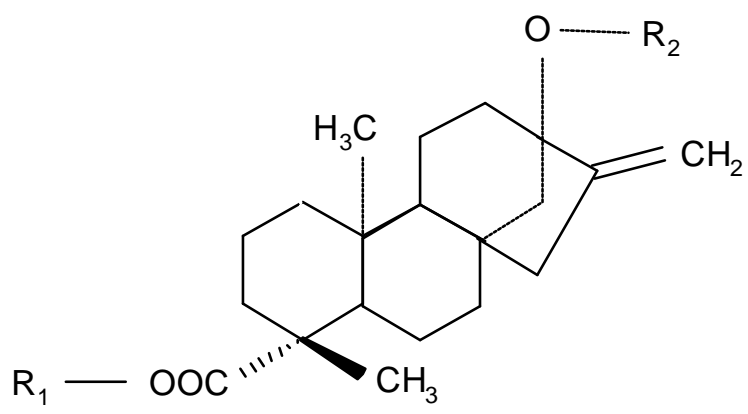

\begin{tabular}{|c|c|c|c|}
\hline Deterpene glycoside & $\mathbf{R}_{1}{ }^{a}$ & $\mathbf{R}_{2}{ }^{\mathbf{a}}$ & $\begin{array}{c}\text { Sweening potency } \\
(\text { sucrose }=1)\end{array}$ \\
\hline Steviolbioside & $\mathrm{H}$ & $\mathrm{glc}^{2}-1$ glc & $100^{--} 125$ \\
\hline Rubusoside & glc & glc & $100^{--} 120$ \\
\hline Stevioside & glc & $\mathrm{glc}^{2}-{ }^{1} \mathrm{glc}$ & $150^{--} 300$ \\
\hline Rebaudioside A & glc & $\mathrm{glc}_{3}^{2}-{ }_{\mathrm{glc}}^{1} \mathrm{glc}$ & $250-450$ \\
\hline Rebaudioside B & $\mathrm{H}$ & $\mathrm{glc}^{2}-{ }_{\mathrm{glc}}{ }_{\mathrm{glc}}^{\mathrm{glc}}$ & $300-350$ \\
\hline $\begin{array}{l}\text { Rebaudioside C } \\
\text { (dulcoside B) }\end{array}$ & glc & $\mathrm{glc}_{3}{ }^{2-}{ }^{1} \mathrm{rhm}$ & $500^{--} 120$ \\
\hline Rebaudioside D & $\mathrm{glc}^{2--^{1}} \mathrm{glc}$ & $\mathrm{glc}^{2}{ }^{2-}{ }_{\mathrm{glc}}^{\mathrm{l}} \mathrm{glc}$ & $250^{--} 450$ \\
\hline Rebaudioside E & $\mathrm{glc}^{2}-^{1} \mathrm{glc}$ & $\mathrm{glc}^{2-L^{1}} \mathrm{glc}$ & $150^{--} 300$ \\
\hline Dulcoside A & glc & $\mathrm{glc}^{2}{ }^{2}{ }^{1}$ rham & $50--120$ \\
\hline
\end{tabular}

a glc, $\beta$-D-glucopyranosyl; rham, $\alpha$-L-rhamnopyranosyl.

Figure 1: Structure of some stevia glycosides (Crammer and Ikan, 1987). 


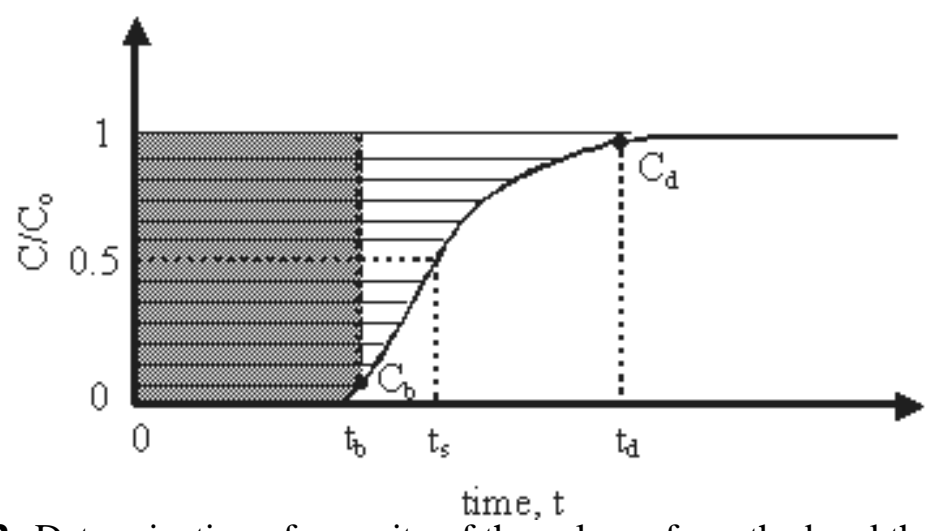

Figure 2: Determination of capacity of the column from the breakthrough curve.

\section{Breakthrough Concentration Curve}

Geankoplis (1993) presents how to calculate the length of unused bed $\left(\mathrm{H}_{\mathrm{UNB}}\right)$, i. e., the width of the mass-transfer zone in the bed. When the entire bed comes to equilibrium with the feed, the total capacity of the bed can be shown to be proportional to the area between the curve and a line at $\mathrm{C} / \mathrm{Co}=1$, as shown in Fig. 2. The total shaded area represents the total stoichiometric capacity of the bed as follows:

$$
\mathrm{t}_{\mathrm{t}}=\int_{0}^{\infty}\left(1-\frac{\mathrm{C}}{\mathrm{Co}}\right) \mathrm{dt}
$$

where $t_{t}$ is the time equivalent to the total or stoichiometric capacity. The usable capacity of the bed up to the break-point time $\mathrm{t}_{\mathrm{b}}$ is the crosshatched area.

Geankoplis (1993) also shows how to calculate $t_{u}$, which is the time equivalent to the usable capacity or the time at which the effluent concentration reaches its maximum permissible value. The value of $t_{t}$ is usually very close to that of $t_{b}$, which is the time at which the concentration at the outlet reaches the permitted values. At this point, the flow must be stopped and the column must be recovered.

$$
\mathrm{t}_{\mathrm{u}}=\int_{0}^{\mathrm{t}_{\mathrm{b}}}\left(1-\frac{\mathrm{C}}{\mathrm{C}_{0}}\right) \mathrm{dt}
$$

The ratio $t_{u} / t_{t}$ is the fraction of total bed capacity or length utilised up to the break point (when $\mathrm{C} / \mathrm{C}_{\mathrm{o}}=$ 0.05 or $\mathrm{A} / \mathrm{A}_{\mathrm{o}}=0.05$ in this work). Hence, for total length of $\mathrm{H}_{T} \mathrm{~m}, \mathrm{H}_{\mathrm{B}}$ is the length of bed used up to the break point.

$$
\mathrm{H}_{\mathrm{B}}=\frac{\mathrm{t}_{\mathrm{u}}}{\mathrm{t}_{\mathrm{t}}} \times \mathrm{H}_{\mathrm{T}}
$$

The length of unused bed $\mathrm{H}_{\mathrm{UNB}}$ in $\mathrm{m}$ is then the unused fraction times the total length.

$\mathrm{H}_{\mathrm{UNB}}=\left(1-\frac{\mathrm{t}_{\mathrm{u}}}{\mathrm{t}_{\mathrm{t}}}\right) \times \mathrm{H}_{\mathrm{T}}$

In the design of an adsorption column, it is important to minimise the length of unused bed $\left(\mathrm{H}_{\mathrm{UNB}}\right)$. This length represents the length of the mass-transfer zone, which is the part of the column where the adsorbent is not completely used and but where adsorption is still occurring. The length of used bed $\left(\mathrm{H}_{\mathrm{U}}\right)$ represents the part of the column in which the adsorbent is completely saturated by the adsorvate.

It is also important to maximise the overall masstransfer coefficient $\left(\mathrm{K}_{\mathrm{C}} \mathrm{a}\right)$, which includes the internal coefficient as well as the external coefficient. Thus, it is not possible to predict from the $\mathrm{K}_{\mathrm{C}} \mathrm{a}$ which is the controlling step in this process of adsorption. But in very favourable cases of adsorption in which the external film controls the rate of adsorption, McCabe et al. (1985) suggest analysis of the $\mathrm{C} / \mathrm{Co} \times \mathrm{N}(\tau-1)$ graph, where $\mathrm{N}(\tau-1)=1+\ln (\mathrm{C} / \mathrm{Co})$ and $\tau$ is dimensionless time. According to Barros et al. (2001), $\tau$ is the same as $t_{u} / t_{t}$ at the break point; thus it is possible to calculate the value of $\mathrm{N}$, and according to McCabe et al. (1985), $\mathrm{K}_{\mathrm{C}} \mathrm{a}$ is given by the following equation:

$\mathrm{K}_{\mathrm{c}} \mathrm{a}=\frac{\mathrm{N} \times \mathrm{u}_{\mathrm{o}}}{\mathrm{H}_{\mathrm{T}}}$

where $\mathrm{N}$ is the number of mass-transfer units, $\mathrm{H}_{\mathrm{T}}$ is the length of the bed and $u_{O}$ is the superficial velocity of the fluid.

Generally these curves have forms represented in the following illustration: 


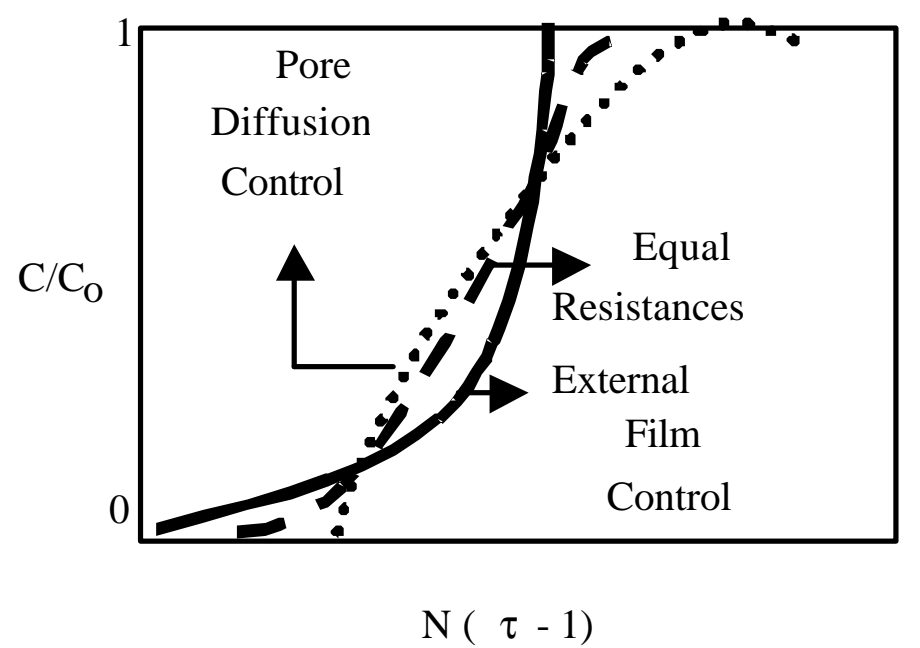

Figure 3: Breakthrough curve for irreversible adsorption (McCabe et al., 1985).

The output concentration given by the breakthrough curves may be analysed using the linearised form of the Thomas equation.

$\log \left[\frac{\mathrm{C}_{0}}{\mathrm{C}}-1\right]=\frac{\mathrm{k} \times \mathrm{X}_{\mathrm{m}} \times \mathrm{M}}{\mathrm{Q}}-\frac{\mathrm{k} \times \mathrm{C}_{0} \times \mathrm{V}}{\mathrm{Q}}$

The maximum adsorption capacity of the bed $\left(\mathrm{X}_{\mathrm{m}}\right)$ and the Thomas rate constant $(\mathrm{k})$ can be determined by plotting $\log [\mathrm{Co} / \mathrm{C}-1]$ (or $\log \left[\mathrm{A}_{\mathrm{o}} / \mathrm{A}\right.$ $1]$ in this work) against filtrate volume (V). Q is the volumetric flow rate (Addour et al., 1999).

This work aims to study the effect of temperature and flow rate on the clarification of aqueous stevia extract in a fixed-bed column with zeolite. With the breakthrough data it was possible to calculate the length of unused bed $\left(\mathrm{H}_{\mathrm{UNB}}\right)$, the length of used bed $\left(\mathrm{H}_{\mathrm{U}}\right)$, the overall mass-transfer coefficient $\left(\mathrm{K}_{\mathrm{c}} \mathrm{a}\right)$, the Thomas rate constant $(\mathrm{k})$ and the maximum capacity of the bed following according to the Thomas model $\left(\mathrm{X}_{\mathrm{m}}\right)$.

\section{MATERIALS AND METHODS}

Stevia leaves were supplied by Steviafarma S. A. (Maringá, Brazil) and granular zeolite, type $\mathrm{NaX}$ $\left(\% \mathrm{Al}_{2} \mathrm{O}_{3}=30.3 ; \% \mathrm{SiO}_{2}=52.6 ; \mathrm{Na}_{2} \mathrm{O}=17.1\right.$; $\mathrm{Si} / \mathrm{Al}$ ratio $=1.47$; diameter $=2-4 \mathrm{~mm}$ ) was supplied by Bayer do Brasil S. A.

\section{Preparation Stevia Extract}

One part of Stevia leaves was used with nine parts of water. First, the water was heated to $55^{\circ} \mathrm{C}$ and then mixed with the stevia leaves and steeped during 30 minutes. After cooling the aqueous extract was filtered in a paper filter.

\section{Ion Exchange Zeolite}

Ion exchange was carried out in zeolites, according to the methodology of Silva et al. (1999). A solution of $\mathrm{CaCl}_{2}$ was used in a batch reactor under magnetic stirring and $\mathrm{pH}$ at 5.5. After 30 minutes, the zeolite was filtered and dried for 24 hours at $100^{\circ} \mathrm{C}$.

\section{Adsorption Column}

The equipment used to obtain the breakthrough curves is represented in Figure 4. Initially, the zeolite was placed in the glass column with a length of $19 \mathrm{~cm}$ and an internal diameter of $1 \mathrm{~cm}$. During about one hour water flowed through the column for degassing air bubbles at a flow rate of about 20 $\mathrm{mL} / \mathrm{min}$. Afterwards, the flow rate was set at the required flow rate $(2,5,9,12,16$ and $19 \mathrm{~mL} / \mathrm{min})$. The water flow was interrupted and the aqueous stevia extract started flowing into the fixed-bed in an ascendant flow. Samples were collected at the outlet of the column during predetermined intervals of time and analysed in a spectrophotometer (SHIMADZU UV 1601 PC), according to Fuh and Chiang (1990). $t_{b}$ was defined as the time when $\mathrm{A} / \mathrm{A}_{\mathrm{o}}$ (instead of $\mathrm{C} / \mathrm{C}_{\mathrm{o}}$ ) is equal to 0.05 and $\mathrm{H}_{\mathrm{UNB}}$ and $\mathrm{H}_{\mathrm{U}}$ were calculated. Absorbance in a range from 300 to 700 $\mathrm{nm}$ was measured for each sample, and the value for the peak close to $671 \mathrm{~nm}$ was taken, which sometimes was slightly displaced from this value. 


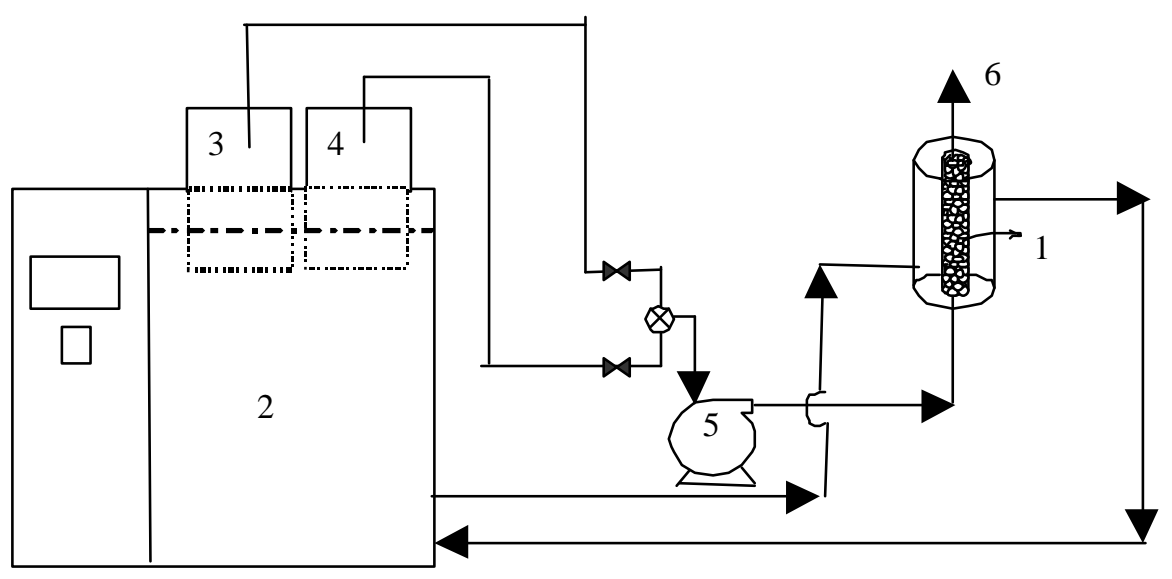

1. Zeolite Bed

2. Thermostatic Bath

3. Reservoir of Water

4. Reservoir of Stevia Extract

5. Peristaltic Pump

6. Sampling

Figure 4: Apparatus for breakthrough curves in an adsorption column.

\section{RESULTS AND DISCUSSION}

The breakthrough curves are presented in Figures 5 to 8 . A zoom of the graph (Fig. 6 and 8) was also done so that it was possible to see the difference between them.

Figures 5, 6, 7 and 8 show that the breakthrough curves have almost the same shape for flow rates higher than $9 \mathrm{~mL} / \mathrm{min}$ and that they are even parallel. For 2 and $5 \mathrm{~mL} / \mathrm{min}$ the breakthrough curve has a spread shape.

The best results were obtained at $10^{\circ} \mathrm{C}$, which was also verified by Moraes and Machado (1999). They also studied the effect of temperature on the same clarification process in a batch reactor, and their results showed that the higher the temperature, the worse the clarification process was. Figure 9 shows that $\mathrm{H}_{\mathrm{UNB}}$ reaches a maximum value for both temperatures at $9 \mathrm{~mL} / \mathrm{min}$. The effect of temperature on the $\mathrm{H}_{\mathrm{UNB}}$ is the biggest exactly at this flow rate and also at $12 \mathrm{~mL} / \mathrm{min}$, where we can see that the difference between $\mathrm{H}_{\mathrm{N} B}$ at $10^{\circ} \mathrm{C}$ and $30^{\circ} \mathrm{C}$ is about $40 \mathrm{~mm}$. For others flow rates, this effect is not so pronounced. For $19 \mathrm{~mL} / \mathrm{min}$, it was also verified that $\mathrm{H}_{\text {UNB }}$ has almost the same value, which means that at high flow rates temperature barely affects $\mathrm{H}_{\mathrm{UNB}}$, so temperature does not matter. At this point, we can say that the best results were obtained at the highest flow rate $(19 \mathrm{~mL} / \mathrm{min})$ where $\mathrm{H}_{\mathrm{UNB}}$ is minimised.

Table 1 shows that $\mathrm{K}_{\mathrm{C}}$ a gets larger as the flow rate increases. Moreover, the values for $10^{\circ} \mathrm{C}$ are slightly higher than those for $30^{\circ} \mathrm{C}$, except for 2 and $16 \mathrm{~mL} / \mathrm{min}$. This is a typical behaviour for processes where diffusion in the external film controls adsorption. Thus, we can also say that the best results were obtained at $19 \mathrm{~mL} / \mathrm{min}$ where $\mathrm{K}_{\mathrm{c}} \mathrm{a}$ is the biggest. Moraes (2000) verified that as temperature decreases clarification improves, and this can also explain the difference between the values for $10^{\circ} \mathrm{C}$ and $30^{\circ} \mathrm{C}$.

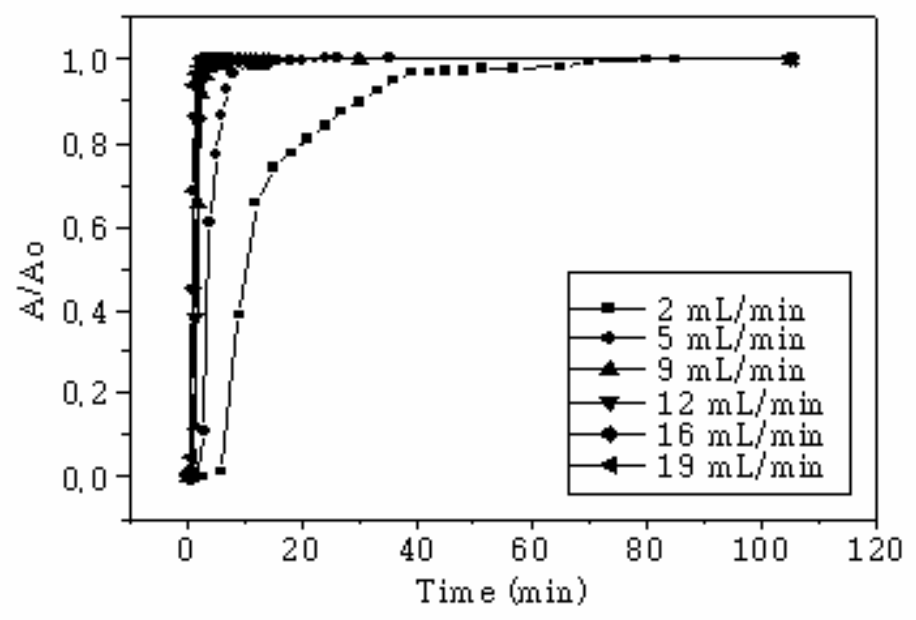

Figure 5: Breakthrough curves at $10^{\circ} \mathrm{C}$ : time 0 to 120 minutes. 


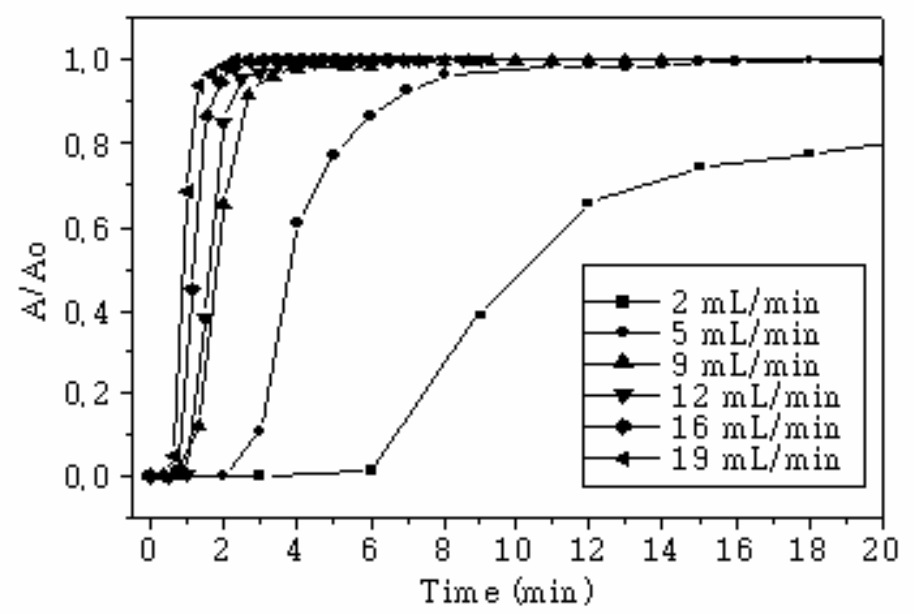

Figure 6: Breakthrough curves at $10^{\circ} \mathrm{C}$ : time 0 to 20 minutes.

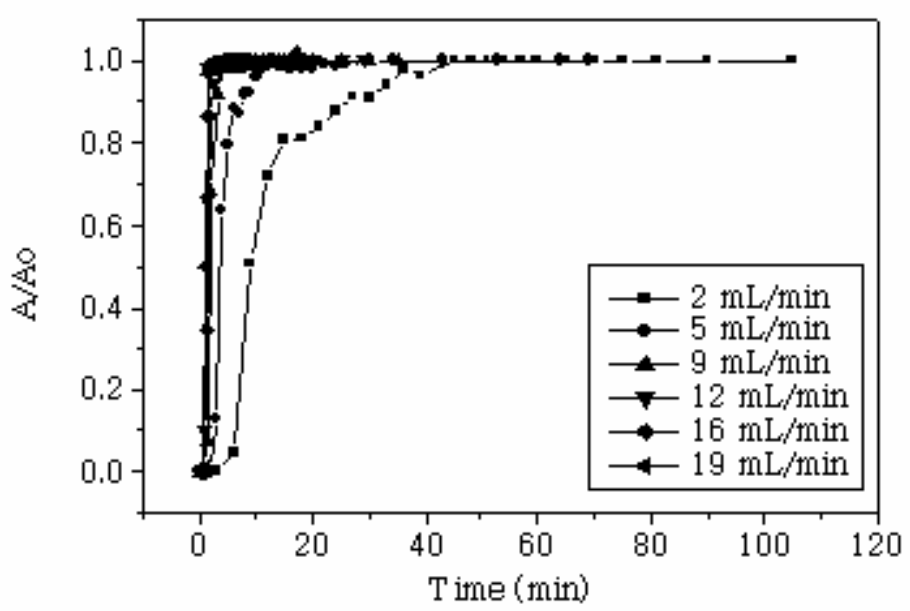

Figure 7: Breakthrough curves at $30^{\circ} \mathrm{C}$ : time 0 to 120 minutes.

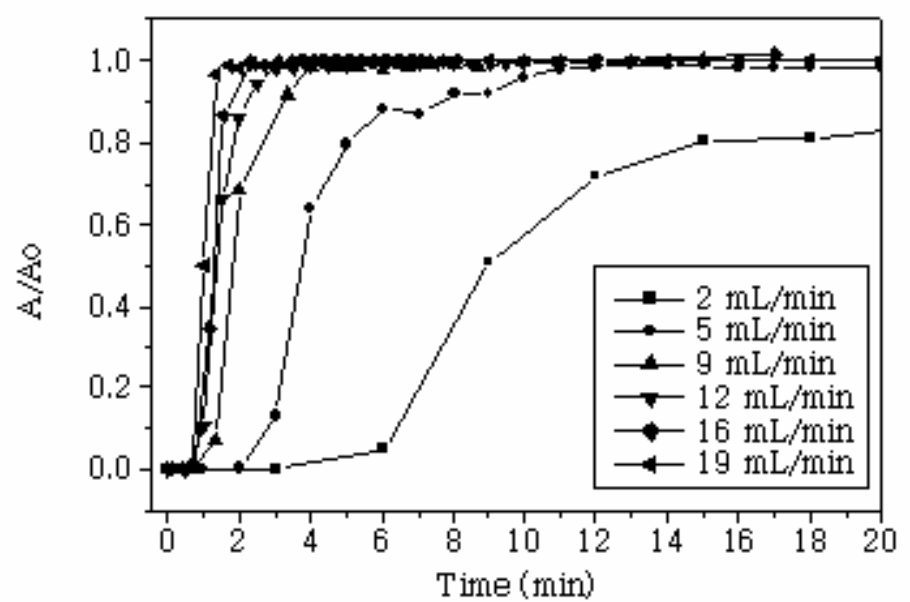

Figure 8: Breakthrough curves at $30^{\circ} \mathrm{C}$ : 0-20 minutes. 


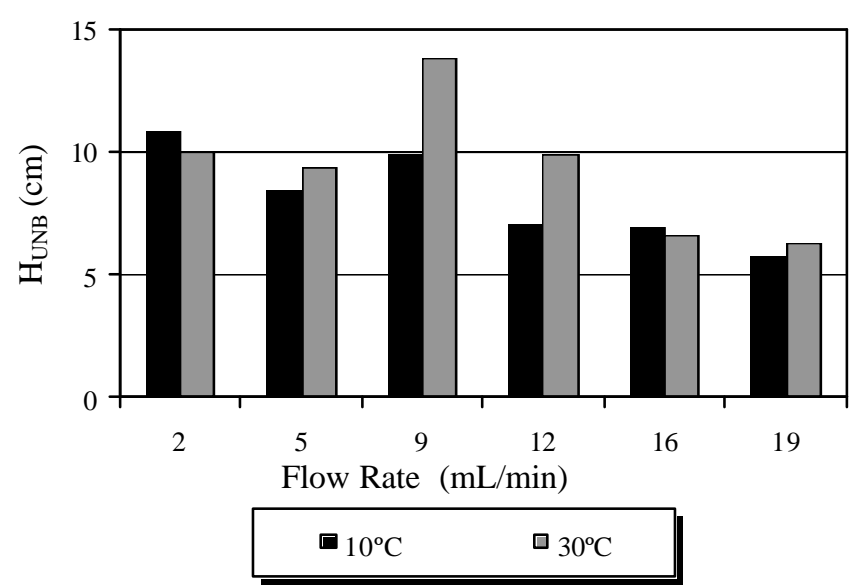

Figure 9: The effect of flow rate and temperature on the length of unused bed $\left(\mathrm{H}_{\mathrm{UNB}}\right)$.

Table 1: The effect of flow rate and temperature on the overall mass-transfer coefficient $\left(K_{C} a\right)$.

\begin{tabular}{|c|c|c|}
\hline \multirow{2}{*}{$\begin{array}{c}\text { Flow Rate } \\
(\mathbf{m L} / \mathbf{m i n})\end{array}$} & \multicolumn{2}{|c|}{$\mathbf{K}_{\mathbf{C}} \mathbf{a}\left(\mathbf{m i n}^{\mathbf{- 1}}\right)$} \\
\cline { 2 - 3 } & $\mathbf{1 0} \mathbf{C}$ & $\mathbf{3 0} \mathbf{C}$ \\
\hline 2 & 0.59 & 0.64 \\
5 & 1.90 & 1.71 \\
9 & 2.90 & 2.07 \\
12 & 5.45 & 3.87 \\
16 & 7.37 & 7.72 \\
19 & 10.48 & 9.67 \\
\hline
\end{tabular}

However, it is still useful to make the following analysis, suggested by McCabe et al. (1985) shown in Fig. 3. Figure 10 just represents one of the A/Ao versus $1+\ln \mathrm{A} / \mathrm{Ao}$ curves for $10^{\circ} \mathrm{C}$ and $2 \mathrm{~mL} / \mathrm{min}$, but it was observed that all curves have basically the same shapes which indicates the control of adsorption by diffusion in the external film.

Even so, comparing Fig. 10 and Fig. 3, we can say that diffusion through the film is probably the controlling step in adsorption. This had been expected since pigments in the Stevia extract are extremely large molecules and their diffusion in the zeolite pores and, more importantly, in the pores of the grain is limited.
In Table 2 the parameters of the Thomas model, which were calculated by linear regression, are presented. The linearised Thomas equation does not describe the breakthrough data very well since the values for $R^{2}$ were not very good, mainly at $30^{\circ} \mathrm{C}$. Figure 11 shows that as $\mathrm{Q}$ increases the values for $\mathrm{k}$ also increase. When $\mathrm{Q}$ reaches $12 \mathrm{~mL} / \mathrm{min}$, the Thomas rate constant $(\mathrm{k})$ is bigger at $10^{\circ} \mathrm{C}$ than $30^{\circ} \mathrm{C}$, but $\mathrm{k}$ is practically the same from 2 to $9 \mathrm{~mL} / \mathrm{min}$. On the other hand, $\mathrm{Xm}$ barely changes with the flow rate at $30^{\circ} \mathrm{C}$, but at $10^{\circ} \mathrm{C}$ the maximum value is for 12 $\mathrm{mL} / \mathrm{min}$ and the other flow rates are of practically the same values as at $30^{\circ} \mathrm{C}$ (Fig. 12).

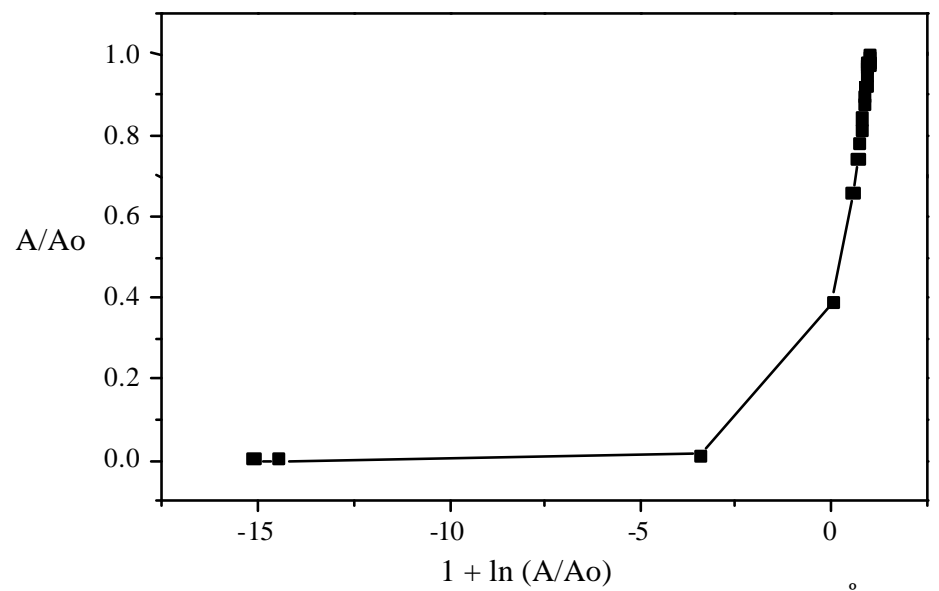

Figure 10: Breakthrough curve using A/Ao vs. $1+\ln (\mathrm{A} / \mathrm{Ao}): 10^{\circ} \mathrm{C}$ and $2 \mathrm{~mL} / \mathrm{min}$. 
Table 2: Parameters of the Thomas model.

\begin{tabular}{|c|c|c|c|c|}
\hline Temperature $\left.\mathbf{~}^{\mathbf{0}} \mathbf{C}\right)$ & $\mathbf{Q}(\mathbf{m L} / \mathbf{m i n})$ & $\mathbf{k}\left(\mathbf{A U}^{-\mathbf{1}} \mathbf{m i n}^{-\mathbf{1}}\right)$ & $\mathbf{X}_{\mathbf{m}} \mathbf{( A U} \mathbf{~ m L} \mathbf{~ g}$ of zeolite) & $\mathbf{R}^{\mathbf{2}}$ \\
\hline & 2 & 0.0186 & 4.33 & 0.7336 \\
& 5 & 0.0831 & 2.82 & 0.8717 \\
& 9 & 0.1952 & 2.50 & 0.8090 \\
& 12 & 0.3192 & 3.01 & 0.9060 \\
& 16 & 0.8001 & 4.22 & 0.9237 \\
& 19 & 0.8994 & 4.00 & 0.8682 \\
\hline \multirow{3}{*}{30} & 2 & 0.0197 & 1.71 & 0.9255 \\
& 5 & 0.0499 & 2.48 & 0.5472 \\
& 9 & 0.2016 & 2.66 & 0.5827 \\
& 12 & 0.2377 & 7.68 & 0.4496 \\
& 16 & 0.5456 & 4.73 & 0.7623 \\
& 19 & 0.4980 & 3.39 & 0.5827 \\
\hline
\end{tabular}

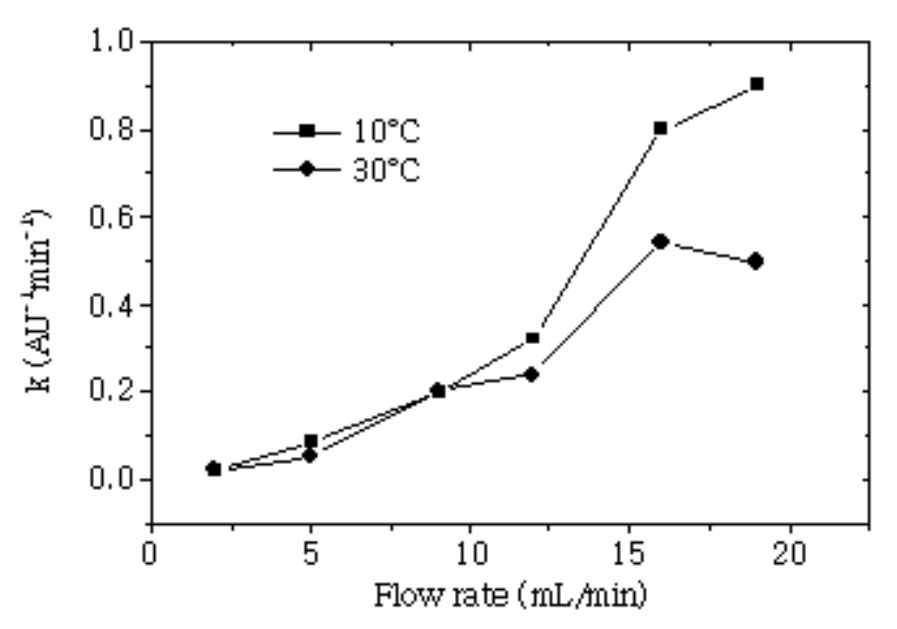

Figure 11: Thomas rate constant $\mathrm{k}\left(\mathrm{AU}^{-1} \mathrm{~min}^{-1}\right)$ vs. flow rate.

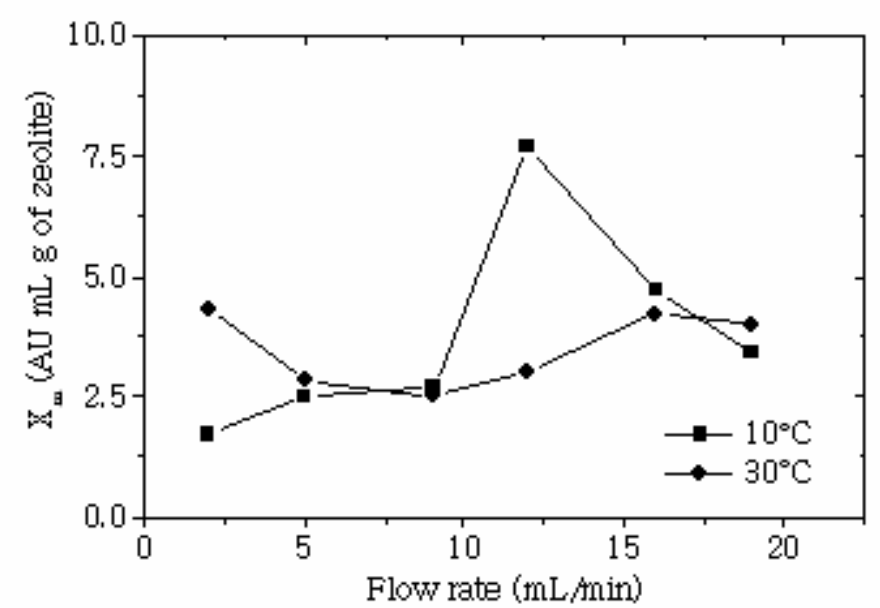

Figure 12: Maximum capacity of the bed with the Thomas model $\left(X_{m}\right)$ vs. flow rate. 


\section{CONCLUSIONS}

As the temperature increases, the length of unused bed $\left(\mathrm{H}_{\mathrm{UNB}}\right)$ also increases, but for high values of flow rate this effect is very small and the length of unused bed is practically the same. For both temperatures, as the flow rate increases, there is a maximum for $\mathrm{H}_{\mathrm{UNB}}$ at $9 \mathrm{~mL} / \mathrm{min}$. The values of $\mathrm{K}_{\mathrm{ca}}$ increase with the flow rate. The mechanism that controls adsorption is diffusion through the external film. The best flow rate was $19 \mathrm{~mL} / \mathrm{min}$ because $\mathrm{H}_{\mathrm{UNB}}$ was minimised and $\mathrm{K}_{\mathrm{c}} \mathrm{a}$ was maximised. The brownish pigments of the stevia extract are large molecules that are not able to penetrate in the pores of the particles. Moreover, after the experiments, it was possible to see that all the external surface of the particles was completely brownish, but when the particles were broken into many parts the original colour of the particles was verified. Despite the fact that these pigment molecules are larger than zeolite pores, adsorption probably takes place on the external surface of the zeolite or even just one small portion of the molecule is able to penetrate the zeolite pores, which makes adsorption possible. It must be clear that the clarification process is intended to adsorb the pigments that make the extract brownish, and not the glycosides, which are responsible for the sweet taste of the extract. Moreover, Moraes and Machado (2000) showed that glycosides are not adsorbed in the zeolite pores.

In order that equations 3 and 4 can be used it is necessary that the adsorption isotherm be favourable or linear. In the case of the stevia extract the adsorbed substances are a complex mixture of pigments, which makes it difficult to get a separate isotherm for each pigment. Even though they did not have measured equilibrium data, Moraes (2000) showed that the adsorption of these pigments in zeolites is very favourable, and this was also confirmed by us in our laboratory.

On the other hand, the use of synthetic zeolite seems to be more safer than the use of natural zeolites, such clinoptilolite, since these synthetic zeolites are free of impurities like heavy metals, which would be a problem in food applications.

Finally, the good quality of the extract when A/Ao is 0.05 in the effluent of the column is very good for the industry of this sweetener, and zeolites seems to be a promising adsorbent for this clarification process.

\section{ACKNOWLEDGMENTS}

The authors wish to thank Steviafarma S.A., which gave us samples of stevia leaves, and Prof.
Nádia Regina C. F. Machado (Department of Chemical Engineering, State University of Maringá), who gave us samples of zeolite.

\section{NOMENCLATURE}

A Absorbance at the outlet of the fixed-bed column (Absorbance Unit, AU)

Ao Absorbance at the inlet of the fixed-bed column (Absorbance Unit, AU)

$\mathrm{H}_{\mathrm{U}} \quad$ Length of the used bed (mm)

$\mathrm{H}_{\mathrm{UNB}} \quad$ Length of the unused bed (mm)

$\mathrm{H}_{\mathrm{T}} \quad$ Length of the bed (mm)

$\mathrm{K}_{\mathrm{C}} \mathrm{a} \quad$ Overall mass-transfer coefficient $\left(\mathrm{min}^{-1}\right)$

MTZ Mass-transfer zone

$\mathrm{N} \quad$ Number of mass-transfer units

$\tau \quad$ Dimensionless time

$\mathrm{k} \quad$ Thomas rate constant $\left(\mathrm{AU}^{-1} \min ^{-1}\right)$

$\mathrm{X}_{\mathrm{m}} \quad$ Maximum capacity of the bed using the Thomas model (AU $\mathrm{mL} g$ of zeolite)

M Mass of the adsorbent $(\mathrm{g})$

$\mathrm{V} \quad$ Filtrate volume $(\mathrm{mL})$

Q Volumetric flow rate $(\mathrm{mL} / \mathrm{min})$

\section{REFERENCES}

Addour, L., Belhocine, D., Boudries, N., Comeau, Y., Pauss, A. and Nameri, N., Zinc Uptake by Streptomyces rimosus Biomass Using a Packedbed Column. Journal of Chemical Technology and Biotechnology, 74, 1089-1095 (1999).

Barros, M.A.S.D., Araújo Jr., I.F., Arroyo, P.A., Sousa-Aguiar, E.F. and Tavares, C. R.G., Estimation of Mass Transport Parameters for Fixed-bed $\mathrm{NaY}, 3^{\text {rd }}$ Mercosur Congress on Process Systems Engineering, Proceedings of ENPROMER, Santa Fé - Argentina, Vol. 2, 11111116 (2001).

Brandle, J.E., Starratt, A.N. and Gijzen, M., Stevia rebaudiana: Its Agricultural, Biological, and Chemical Properties. Canadian Journal of Plant Science, 78(4), 527-536 (1998).

Crammer, B. and Ikan, R., Progress in the Chemistry and Properties of Rebaudiosides, In: Developments in Sweeteners, Vol. 3, ed. T.H. Grenby. Elsevier Applied Science, London, (1987).

Fuh, W.S. and Chiang, B.H., Purification of Stevioside by Membrane and Ion Exchange Process. Journal Food of Science. 55 (5), 14541457 (1990). 
Geankoplis, C.J., Transport Processes and Unit Operation, PTR Prentice Hall, $3^{\text {d }}$ Edition, New Jersey, 702-704 (1993).

Kodaka, K., Purification of Sugar Solution from Stevia Dry Leaves, Japan. Kokai Pat. Appl. 76/27, 634 (Cl. A23L1/22), 3pp, (1977).

McCabe, W.L., Smith, C.J. and Harriott, P., Unit Operations of Chemical Engineering, McGrawHill International Editions, $4^{\text {th }}$ Edition, Singapore, 692-702 (1985).

Moraes, E.P., Clarificação do Extrato de Stévia Rebaudiana Bertoni Através de Adsorção em Zeolita Modificada. Master's thesis in Chemical Engineering, State University of Maringá (2000).

Moraes, E.P. and Machado, N.R.C.F., Purification of the Extract of Stevia rebaudiana Bertoni Through Adsorption in Modified Zeolites. VI Seminar on Enzymatic Hydrolysis of Biomass, Proceeding of VI SHEB, CD-ROM, Maringá (1999).

Nishiyama, P., Alvarez, M. And Vieira, L.G.E., Quantitative Analysis of Stevioside in the Leaves of Stevia rebaudiana by Near Infrared Reflectance Spectroscopy. Journal of the Science of Food and Agriculture, 59(3), 277-281 (1992).

Phillips, K.C., Stevia: Steps in Developing a New Sweetener, In: Developments in Sweeteners, Vol. 3, ed. T.H. Grenby. Elsevier Applied Science,
London (1987).

Shi, R., Xu, M., Shi, Z., Fan, Y., Guo, X., Liu, Y., Wang, C. and He, B., Synthesis of Bifunctional Polymeric Adsorbent and Its Application in Purification of Stevia Glycosides. Reactive and Functional Polymers, 50, 107-116 (2002).

Silva, C.F., Yoshida, C.K.C., Machado, N.R.C.F. and Maugeri Filho, F., Efeito do Tempo de Troca Iônica de Metais Alcalinos na Acidez/Basicidade de Zeólitas. Acta Scientiarum. 21(4), 760-772 (1999).

Suttajit, M., Vinitketkaumnuem, U., Meevatee, U. And Buddhasukh, D., Mutagenicity and Human Chromosomal Effect of Stevioside, a Sweetener From Stevia rebaudiana Bertoni. Environmental Health Perspective, 101 (Suppl.3), 53-56 (1993).

Xili, L., Chengjiany, B., Eryi, X., Reiming, S., Yuenming, W., Haodong, S., and Zhiyian, H., Chronic Oral Toxicity and Carcinogenicity Study of Stevioside in Rats. Food and Chemical Toxicology, 30, 957-965 (1992).

Yodyinguard, V. and Bunyawong, S., Effect of Stevioside on Growth and Reproduction. Human Reproduction, 6, 158-165 (1991).

Zhang, S.Q., Kutowy, O. and Kumar, A., Stevia rebaudiana Leaves - a Low Calorie Source of Sweeteners. Canadian Chemical News, 51(5), 2224 (1999). 